\title{
sciendo
}

\section{PHYSICOCHEMICAL CHARACTERISTICS OF FERTILIZER INDUSTRY EFFLUENT AND ITS TOXICOLOGICAL IMPACT ON THE ACTIVITY OF ACETYLCHOLINESTERASE (AChE) IN FRESHWATER TELEOSTS Heteropneustes fossilis AND Labeo rohita}

\author{
Upma Singh, Rishikesh K. Tiwari, Ravi S. Pandey* \\ Biochemistry Laboratory, Department of Zoology, University of Allahabad, Allahabad-211002, Uttar-Pradesh, \\ India
}

*Corresponding Author, Email: rspandey2004@yahoo.com

\section{ARTICLE INFO}

Received: 17 November 2018

Accepted: 13 March 2019

\begin{abstract}
Industrial revolution is a good indicator of economic development of a country; however, it can be a threat to the flora and fauna if the untreated effluent of an industry is discharged. The present study is aimed to assess the comparative toxicological impacts of treated and untreated industrial effluents on acetylcholinesterase (AChE) activity in Heteropneustes fossilis and Labeo rohita, the most common edible fishes having diverse characters which include differences in morphology, habitat, food and feeding, etc. The physico-chemical parameters such as $\mathrm{pH}$, electrical conductivity (EC), alkalinity, hardness, dissolved oxygen (DO), phosphate, sulphate, nitrate, free ammonia, chloride, zinc, iron, chromium and potassium of both untreated and treated effluent from the fertilizer industry were also analyzed as these parameters were not in range as per ISO guidelines. The $\mathrm{LC}_{50}$ value for untreated effluent was $2.34 \%(\mathrm{v} / \mathrm{v})$ and $0.80 \%(\mathrm{v} / \mathrm{v})$ for $96 \mathrm{~h}$ in $H$. fossilis and L. rohita, respectively, while no mortality was recorded in the treated effluent. The AChE activity in both fish species was found to decline in metabolically responsive organs like brain, muscle and gills through exposure to sub-lethal concentrations $\left(1 / 15^{\text {th }}, 1 / 10^{\text {th }}\right.$ and $1 / 5^{\text {th }}$ of $\mathrm{LC}_{50}$ value) of the untreated effluent for $96 \mathrm{~h}$. Further studies on biochemical and molecular aspects may reveal the mechanism of their action.
\end{abstract}

Singh, U., Tiwari, R. K., Pandey, R. S. (2019): Physicochemical characteristics of fertilizer industry effluent and its toxicological impact on the activity of acetylcholinesterase (ache) in freshwater teleosts, Heteropneustes fossilis and Labeo rohit. Croatian Journal of Fisheries, 77, 77-86. DOI: 10.2478/ cjf-2019-0008. 


\section{INTRODUCTION}

Fertilizer industries use a variety of chemical compounds due to which the effluents are complex in nature. The effluents are rich in various organic compounds, heavy metals, dissolved and suspended solids. The effluents adversely affect the metabolism of fish inhabiting the aquatic bodies causing mortality and impairment in physiological activities (Bobmanuel et al., 2006; Kaur et al., 2010; Roopadevi and Somasekhar, 2012). On the basis of pollution load, fertilizer producing industries have been categorized under red list industries in India by the Ministry of Environment, Forest and Climate Change (2016).

In the aquatic ecosystem, fish play crucial role in the monitoring of water contamination as they respond in most sensitivity to variations in aquatic pollution (Naigaga et al., 2011). Stinging catfish $H$. fossilis (name "stinging" due to its venomous nature) is a native fish species of India and is economically important due to its nutritive and medicinal value (Talwar and Jhingran, 1991; Tiwari et al., 2017). Its body is elongated and depressed towards head region in order to survive in drastic conditions (e.g. drought, enemy and carnivorous activity) which make them hardy in nature (Jawad, 2015). It is carnivorous in nature, found at benthic region (in mud) during day time and exhibits nocturnal behaviour, i.e. it is much active during night as it frequently comes up for air gulping (Pati et al., 1998). The other species, Labeo rohita, is one of the major and most widespread carp species in India. It is suitable for experimental purposes due to its easy capturing and maintenance in the laboratory and is also economically important. L. rohita is found throughout the year in lakes and rivers of India, has spindle shaped body for floatation purpose and is basically planktivorous (Das and Moitra, 1955).

$\mathrm{LC}_{50}$ is the most reliable and preliminary test for toxicity evaluation in fish (Shenkani and Das, 2014; Shreelekshmy et al., 2016). Acetylcholinesterase (AChE, EC: 3.1.1.7), an acetylcholine (ACh) hydrolyzing enzyme (Gaitonde et al., 2006), plays an important role in neurotransmission in both the vertebrates and invertebrates (Valbonesi et al., 2003). Inhibition of AChE by pesticides, heavy metals or industrial effluents results in ACh accumulation in synaptic cleft, causing neuromuscular paralysis and asphyxiation, resulting finally in mortality (Xuereb et al., 2009; Rakhi et al., 2013). Recent studies suggest that AChE is a very sensitive indicator of stress and hence can be useful for biomonitoring and assessment of the level of contamination (Richetti et al., 2011).

In an era of industrialization, developing countries face a big problem in proper industrial waste treatment prior to its disposal due to technical limitations and heavy economic expenses behind the treatment process (Majumdar et al., 2007). Therefore, an effective management to prevent or at least minimize waste generation by developing technologies for waste recycling and reuse are the need of the hour (Jadhav and Hocheng, 2012). Many ecological incidents occurred in the past across the planet, and there are still high probabilities that untreated industrial effluent may reach the nearby aquatic bodies and adversely affect the organisms living therein. Hence, in the present study an attempt has been made to determine the physicochemical characteristics of both treated and untreated effluents, their acute toxicity and their impact on AChE activity in fishes.

\section{MATERIALS AND METHODS}

\section{Animal maintenance and chemicals}

Fishes, Heteropneustes fossilis and Labeo rohita, were procured from the local fish market (Allahabad, Uttar-Pradesh, India) and treated with potassium permanganate solution $\left(\mathrm{KMnO}_{4}, 0.5 \% \mathrm{w} / \mathrm{v}\right)$ for one min to remove any kind of subcutaneous adherent(s). The fishes were acclimatized in glass aquarium (capacity $50 \mathrm{~L}$ ) with dechlorinated aerated tap water $(\mathrm{pH} 6.8 \pm 0.2$, dissolved oxygen $6.8 \pm 0.5 \mathrm{mg} \mathrm{L}^{-1}$ and total hardness $111.4 \pm 4.0 \mathrm{mg}$ $\left.\mathrm{L}^{-1}\right)$. Before exposure, quality of water was assessed and tested according to the American Public Health Association Guidelines (APHA, 1985). For fifteen days, fishes were acclimatized at room temperature $\left(26.0 \pm 1.2^{\circ} \mathrm{C}\right)$ and were fed commercially available food pellets (Tokyu, India) ad libitum. All of the chemicals used in the present study were of analytical grade and standard quality.

\section{Experimental design}

\section{Physicochemical analysis}

The untreated and treated samples were collected from a fertilizer production unit situated in Indian Farmers Fertiliser Cooperative Ltd. (IFFCO; Phulpur, Allahabad, India) and brought to the laboratory for physicochemical analysis followed by experimentation. Standard methods were used for the analysis of collected samples. $\mathrm{pH}$ and electrical conductivity (EC) were determined electrometrically. The physicochemical parameters such as alkalinity, hardness, dissolved oxygen, free ammonia and chloride were determined by titration method. Determinations of phosphate, sulphate and nitrate concentrations were done by spectrophotometric methods. Zinc, iron, chromium and potassium concentrations were determined by using atomic absorption spectrophotometer (Perkin Elmer Analyst 200, USA).

\section{Determination of acute toxicity $\left(L C_{50}\right)$}

Feeding was stopped twenty four hours before experimentation. Twelve individuals of $H$. fossilis of average length of $13.0 \pm 2.0 \mathrm{~cm}$ and average weight of $21.0 \pm 2.25 \mathrm{~g}$ were placed in each of the aquaria containing $12 \mathrm{~L}$ of water ( $\mathrm{n}=12 /$ glass aquarium). Untreated and treated effluent samples were added as 
per following concentrations - control, 1.95, 2.10, 2.25, $2.40,2.55,2.70 \%(\mathrm{v} / \mathrm{v})$ and control, 25, 50, 75, 100\% (v/v), respectively. Similarly, twelve individuals of $L$. rohita of average length of $12.0 \pm 1.69 \mathrm{~cm}$ and average weight of $43.0 \pm 1.43 \mathrm{~g}$ were placed in each of the aquaria containing $12 \mathrm{~L}$ of water ( $\mathrm{n}=12 / \mathrm{glass}$ aquarium). Untreated and treated effluent samples were added as per following concentrations - control, 0.75, 0.85, 0.90, 0.95, 1.00, $1.05 \%(\mathrm{v} / \mathrm{v})$ and control, 20, 40, 60, 80 and $100 \%(\mathrm{v} / \mathrm{v})$, respectively. At an interval of twenty four hours, the water of aquaria was changed and different concentrations of fresh effluents were added. Fish kept in effluent-free medium served as the control. The test was performed for $96 \mathrm{~h}$ treatment period and dead fish were removed as the test proceeded. The number of dead fish per group was recorded against the time of their mortality in a tabular form, as specified by Sprague (1969). The $96 \mathrm{~h} \mathrm{LC}_{50}$ value of untreated and treated effluents was calculated using arithmetic method of Kärber (1931), modified by Dede and Kaglo (2001).

\section{Subacute toxicity assays}

\section{Preparation of tissue homogenate}

The fishes were sacrificed by using mild anaesthesia (Trichloromethane) after exposure to three sublethal concentrations of effluents $\left(1 / 15^{\text {th }}\right.$ of $\mathrm{LC}_{50^{\prime}} 1 / 10^{\text {th }}$ of $L C_{50}$ and $1 / 10^{\text {th }}$ of $\mathrm{LC}_{50}$ ) for $96 \mathrm{~h}$. Key organs (brain, muscle and gills) of exposed fishes along with the control were surgically removed and thoroughly rinsed in $0.69 \%$ cold saline, at $4-6^{\circ} \mathrm{C}$ and blotted dry. The tissues were weighed and homogenized $(10 \%, \mathrm{w} / \mathrm{v})$ in $50 \mathrm{mM}$ sodium phosphate buffer ( $\mathrm{pH} 8.0$ ), containing $0.1 \%$ Triton X-100, using Potter-Elvehjam homogenizer fitted with a Tefloncoated pestle under ice cold conditions. For $30 \mathrm{~min}$, the homogenates were kept in cold with intermittent stirring and centrifuged at $4^{\circ} \mathrm{C}$ for $30 \mathrm{~min}$ at $10,000 \mathrm{~g}$ in a refrigerated centrifuge (Model-3K30 Sigma, St. Louis, USA). The corresponding supernatants were used afresh for determination of protein contents by AChE assay.

\section{Assay of Acetylcholinesterase (AChE)}

AChE activity was assayed according to Ellman's method (Ellman et al., 1961). The reaction mixture $(3 \mathrm{~mL})$ contained $1.5 \mathrm{~mL}$ of $100 \mathrm{mM}$ sodium phosphate buffer ( $\mathrm{pH} 8.0), 0.3$ $\mathrm{mL}$ of $5 \mathrm{mM}$ DTNB [5,5'-dithiobis-(2-nitrobenzoic acid), prepared in $10 \mathrm{mM}$ sodium phosphate buffer, $\mathrm{pH} 7.5$ containing $15 \mathrm{mg}$ sodium bicarbonate added per $10 \mathrm{~mL}$ of solution], $0.3 \mathrm{~mL}$ of $5 \mathrm{mM}$ Acetylthiocholine iodide (ATI), $0.1 \mathrm{~mL}$ of supernatant and $0.8 \mathrm{~mL}$ of distilled water. In a UV-visible double beam spectrophotometer (Shimadzu, Model: UV 1800, SL - 02480, Japan), the increase in absorbance was monitored at $412 \mathrm{~nm}$ and $28^{\circ} \mathrm{C}$ for 3 min with quartz cuvettes against distilled water as blank. For each tissue, measurements were made in triplicate. Simultaneously, two blanks were also used. One (enzyme blank) contained phosphate buffer, DTNB and ATI but not the enzyme to determine the spontaneous hydrolysis of ATI, and the second (substrate blank) contained phosphate buffer, DTNB and enzyme protein but no substrate to correct any non-AChE-dependent formation of thionitrobenzoic acid (TNB). One unit of AChE activity was expressed as nanomoles of hydrolyzed substrate/ $\mathrm{min} / \mathrm{mg}$ protein under experimental conditions.

\section{Estimation of protein}

The protein content in cell-free extract of different fish tissues was determined by the method described by Lowry et al. (1951) using bovine serum albumin (BSA) as the standard.

\section{Statistical analysis}

The data of physicochemical parameters are represented as mean \pm SEM. The lethal concentration for $96 \mathrm{~h}$ was calculated by Kärber method (1931) as adopted by Dede and Kaglo (2001), and confidence interval calculated by SPSS 16.0. The data for AChE activity and protein content were represented as mean \pm SEM and were analyzed by the one-way analysis of variance (one-way ANOVA) using SPSS software $(16.0,2008)$. To note the variations between control versus experimental groups and among the experimental groups $\left(1 / 15^{\text {th }}, 1 / 10^{\text {th }}\right.$ and $1 / 5^{\text {th }}$ exposed groups), Duncan's multiple range post hoc test was applied. The results were considered to be significant at $p<0.05$ and $p<0.01$ levels (confidence levels $95 \%$ and $99 \%$, respectively). All experiments were carried out in triplicate and data were statistically analyzed according to Brunning and Knitz (1977).

\section{RESULTS AND DISCUSSION}

\section{Physico-chemical characteristics}

Various physicochemical characteristics like $\mathrm{pH}$, conductivity, alkalinity, hardness, dissolved oxygen, concentration of phosphate, sulphate, nitrate, chloride, zinc, iron, potassium, chromium and free ammonia of untreated and treated fertilizer industry effluents were studied (Table 1). Some of the parameters like $\mathrm{pH}$, conductivity, chloride content, free ammonia and chromium have been found quite high, while dissolved oxygen, concentration of nitrate, zinc and iron were even below the permissible limit of the Bureau of Indian Standards (BIS 10500:1991, 2003). However, others like alkalinity, hardness and the concentration of sulphate, phosphate and potassium were in moderate range.

The $\mathrm{pH}$ of untreated and treated effluent samples was $9.99 \pm 0.17$ and $7.2 \pm 0.048$, respectively, and similarly alkalinity was $627.0 \pm 0.54$ and $192.0 \pm 0.49 \mathrm{mg} \mathrm{L}^{-1}$, respectively. The higher $\mathrm{pH}$ (showing alkalinity) of the untreated sample is probably due to the presence of ammonia which may result in bio-concentration of metals in aquatic organisms and cause adverse effect on their health (Campbell and Stokes, 1985; Karthikeyan et al., 2004; Durrani et al., 2007). Conductivity of water 
Table 1. Comparative account of physico-chemical parameters of the untreated and treated effluent sample (Mean \pm SEM) of the fertilizer industry and their permissible range (BIS 10500: 1991, 2003)

\begin{tabular}{|c|c|c|c|c|c|}
\hline S. No & Parameters & Permissible Range & Untreated effluent & Treated effluent & Method employed \\
\hline 1. & $\mathrm{pH}$ & $6.5-8.2$ & $9.99 \pm 0.17$ & $7.2 \pm 0.048$ & Electrometric \\
\hline 2. & Conductivity & $200\left(\mu \mathrm{Scm}^{-1}\right)$ & $9463 \pm 1.82$ & $217 \pm 1.08$ & Electrometric \\
\hline 3. & Alkalinity & $200(\mathrm{mg} \mathrm{L}-1)$ & $627.0 \pm 0.54$ & $192 \pm 0.49$ & Titrimetric \\
\hline 4. & Hardness & $300-600\left(\mathrm{mg} \mathrm{L}^{-1}\right)$ & $672.0 \pm 0.09$ & $302 \pm 0.84$ & Titrimetric \\
\hline 5. & Dissolved Oxygen & $5\left(\mathrm{mg} \mathrm{L}^{-1}\right)$ & $3.33 \pm 0.09$ & $4.98 \pm 0.23$ & Titrimetric \\
\hline 6. & Phosphate & $5\left(\mathrm{mg} \mathrm{L}^{-1}\right)$ & $7.32 \pm 0.50$ & $5.02 \pm 0.11$ & Spectroscopic \\
\hline 7. & Sulphate & $200-400\left(\mathrm{mg} \mathrm{L}^{-1}\right)$ & $865.0 \pm 1.58$ & $331.8 \pm 0.28$ & Spectroscopic \\
\hline 8. & Nitrate & $45-100\left(\mathrm{mg} \mathrm{L}^{-1}\right)$ & $10.89 \pm 0.57$ & $63.22 \pm 0.88$ & Spectroscopic \\
\hline 9. & Free $\mathrm{NH}_{3}$ & $0-5\left(\mathrm{mg} \mathrm{L}^{-1}\right)$ & $403.6 \pm 0.47$ & $4.7 \pm 0.29$ & Titrimetric \\
\hline 10. & Chloride & $250-1000\left(\mathrm{mg} \mathrm{L}^{-1}\right)$ & $1667.2 \pm 0.56$ & $857.2 \pm 0.96$ & Titrimetric \\
\hline 11. & Zinc & $<2\left(\mathrm{mg} \mathrm{L}^{-1}\right)$ & $0.132 \pm 0.01$ & $1.97 \pm 0.05$ & $\begin{array}{l}\text { Atomic Absorption } \\
\text { Spectrophotometric }\end{array}$ \\
\hline 12. & Iron & $1.0\left(\mathrm{mg} \mathrm{L}^{-1}\right)$ & $0.079 \pm 0.01$ & $0.92 \pm 0.03$ & $\begin{array}{l}\text { Atomic Absorption } \\
\text { Spectrophotometric }\end{array}$ \\
\hline 13. & Potassium & $<20\left(\mathrm{mg} \mathrm{L}^{-1}\right)$ & $26.67 \pm 0.72$ & $19.20 \pm 0.82$ & $\begin{array}{l}\text { Atomic Absorption } \\
\text { Spectrophotometric }\end{array}$ \\
\hline 14. & Chromium & $0.05\left(\mathrm{mg} \mathrm{L}^{-1}\right)$ & $1.274 \pm 0.09$ & $0.06 \pm 0.01$ & $\begin{array}{l}\text { Atomic Absorption } \\
\text { Spectrophotometric }\end{array}$ \\
\hline
\end{tabular}

shows the ability of solvent to conduct electricity which depends on the presence of ions and their concentrations (Abdullah and Musta, 1999). Conductivity is significantly correlated to the $\mathrm{pH}$, alkalinity, hardness, concentrations of phosphate, sulphate, free ammonia, chloride, ion mobility and temperature, and is an indicator of salinity or total salt content of discharged effluent (Kumar and Sinha, 2010). A quite higher level of conductivity in the untreated effluent than in the treated one is probably due to the presence of a higher level of nitrate, free ammonia, chromium content, etc. (Table 1). Hardness is a measure of capacity of water to precipitate soap, contributed by presence of calcium, magnesium and presence of minerals. The hardness of both the untreated and treated samples was almost close to the permissible range. Dissolved oxygen in the untreated effluent sample was $3.33 \pm 0.09 \mathrm{mg} \mathrm{L}^{-1}$, which is much lower than in the treated one (as per ISO-guidelines). A dissolved oxygen level > 5 $\mathrm{mg} \mathrm{L}^{-1}$ is necessary to support adequately the metabolism and health of fishes (Bhatnagar and Devi, 2013; Nirgude et al., 2013). Thus the observed lower dissolved oxygen recorded in the untreated effluent seems inadequate for the maintenance of good health of fish. Effluent from the fertilizer industry contains a higher level of phosphate and sulphate, therefore higher concentrations of these in the untreated effluent sample were recorded. Increased phosphate results in eutrophication of aquatic ecosystem, which might be a cause for mortality of fish in aquatic system (Grubb et al., 2000; Horrigan et al., 2002). A higher level of chloride content observed in the untreated sample may be due to the usage of hydrochloric acid, hypochloric acid, chlorine gas, etc., as raw materials during various processes. A higher free ammonia and a lower nitrate content in the untreated sample indicates the presence of nitrogen in bound form $\left(\mathrm{NH}_{4} \mathrm{OH}\right)$ which decomposes into free ammonia and water, resulting in increase in ammonia concentration in comparison to the treated effluent (Table 1, Fig. 1). The zinc and iron levels in the untreated effluent sample are close to the permissible range. However, level of potassium is higher than in the treated sample, which may cause physiological imbalance in the fish (Sah et al., 2002). Chromium level is much higher in the untreated effluent sample than in the treated sample. It is non-biodegradable and therefore has potential to cause toxicity and biomagnifications in aquatic organisms (Wicklund-Glynn and Olsson, 1991; Praveena et al., 2013).

\section{Toxicity assessment}

Acute toxicity assessment provides a comparative lethal value of tested effluents in both catfish and carps. The obtained values show susceptibility of fish to particular contaminants and reflect their survival potential. Accordingly, catfish were more tolerant than carps due to their physiological and ecological condition (Abedi et al., 2012). $\mathrm{LC}_{50}$ for $96 \mathrm{~h}$ for the untreated effluent in $\mathrm{H}$. fossilis and L. rohita was determined as 2.35 and $0.85 \%$ (v/v) (confidence interval: $1.94-2.47$ and $0.786-0.958$ ), 


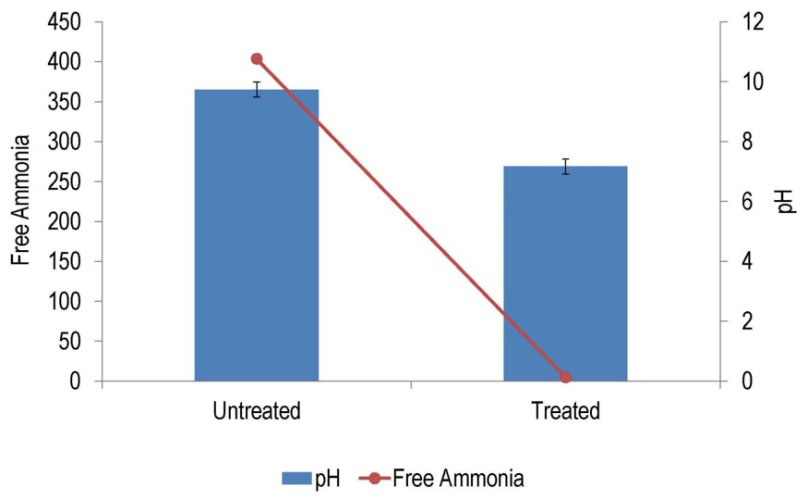

Fig 1. $\mathrm{pH}$ value and concentration of free ammonia in the untreated and treated effluent sample of the fertilizer industry. Data represent mean $\pm S$. E. M.

respectively (Table $2 \& 3$ ). A similar finding was reported by Yadav et al. (2007) and El-Samara et al. (1986) in Channa striatus $(70 \% \mathrm{v} / \mathrm{v})$ and Mugil cephalus $(0.74$ and $0.76 \%$ $\mathrm{v} / \mathrm{v}$ exposed to north and south plant fertilizer effluents, respectively). However, fishes exposed to dechlorinated tap-water and the treated effluent sample were observed to be healthy and normal.

However, reports regarding lethal toxicity in fishes exposed to fertilizer industry effluent are very scanty. Only a few are currently available but for varying exposure duration (shorter than $96 \mathrm{~h}$ ) and for different fish species. The $\mathrm{LC}_{50}$ values at 24,48 and $72 \mathrm{~h}$ were $72.05,30.81$ and $15.26 \%(\mathrm{v} / \mathrm{v})$, respectively, in Oreochromis niloticus, and 26.18, 10.32 and $9.84 \%(\mathrm{v} / \mathrm{v})$, respectively, for hybrid catfish (Heterobranchus bidorsalis $\$$ X Clarias gariepinus ふ) (Bobmanuel et al., 2006). The $\mathrm{LC}_{50}$ values of different industrial effluents for $96 \mathrm{~h}$ exposure of different fish species have been reported. These values were 20, 6 and $22 \%(\mathrm{v} / \mathrm{v})$ in L. rohita for tannery, electroplating and textile effluents, respectively (Muley et al., 2007); 4.21 and $2.5 \%(\mathrm{v} / \mathrm{v})$ in $\mathrm{H}$. fossilis and Lebistus reticulates, respectively, exposed to galvanizing and raw bulk drug industrial effluents (Majumdar et al., 2007; Deshpande and Satyanarayan, 2011); $51.20 \mathrm{~mL} \mathrm{~L}^{-1}$ in Oreochromis niloticus exposed to pharmaceutical effluent and 1.67 $\mathrm{mL} \mathrm{L}^{-1}$ in Poecilia reticulate exposed to chrome plating industrial effluents (Obasi et al., 2014; Ahila Angelin et al., 2015); $0.259 \%$ (v/v) in Lebistus reticulate exposed to the untreated pesticide producing industrial effluent (Chavan et al., 2016). These results suggest that the level of toxicity was dependent on nature of effluents discharged by the industries threatening the inhabiting species.

\section{Acetylcholinesterase activity}

Biological markers are sensitive and cost-effective tools for identifying hazards of environmental contamination. As AChE activity has been shown to be a potential biochemical indicator of toxic stress in different fish species; an attempt has been made to study the effect of fertilizer industrial effluent on its activity in different tissues of $H$. fossilis and L. rohita. After exposure to sublethal concentrations $\left(1 / 15^{\text {th }}, 1 / 10^{\text {th }}\right.$ and $1 / 5^{\text {th }}$ of $\left.L C_{50}\right)$ of the untreated effluent for $96 \mathrm{~h}, \mathrm{AChE}$ activity was found to decrease in a concentration-dependent manner in both fish species. The order of decrease in AChE activity was brain $>$ gills $>$ muscles for all sublethal concentration of the untreated effluent studied, however, no significant change was observed in the treated effluent exposed fishes (Fig 2 and 3).

AChE is a transmembrane protein present in cell membranes of vertebrates and invertebrates (Jebali et al., 2013) which hydrolyzes the neurotransmitter acetylcholine into choline and acetic acid in synapses as well as neuromuscular junctions. However, only scanty information is available related to the impact of

Table 2. $\mathrm{LC}_{50}$ determination value of the untreated fertilizer industry effluent in $\mathrm{H}$. fossilis for $96 \mathrm{~h}$ based on arithmetic method of Kärber (1931) as adopted by Dede and Kaglo (2001)

\begin{tabular}{|c|c|c|c|c|c|}
\hline $\begin{array}{c}\text { Concentration } \\
\%(v / v)\end{array}$ & $\begin{array}{c}\text { Concentration } \\
\text { difference }\end{array}$ & $\begin{array}{l}\text { Number of } \\
\text { alive fish }\end{array}$ & $\begin{array}{l}\text { Number of } \\
\text { dead fish }\end{array}$ & Mean mortality & $\begin{array}{c}\text { Mean mortality } \\
\text { x concentration } \\
\text { difference }\end{array}$ \\
\hline Control & 0 & 12 & 0 & 0 & 0 \\
\hline 1.95 & 0.15 & 12 & 0 & 0 & 0 \\
\hline 2.10 & 0.15 & 10 & 2 & 1 & 0.15 \\
\hline 2.25 & 0.15 & 08 & 4 & 3.0 & 0.45 \\
\hline 2.40 & 0.15 & 05 & 7 & 5.5 & 0.825 \\
\hline 2.55 & 0.15 & 03 & 9 & 08 & 1.20 \\
\hline \multirow[t]{2}{*}{2.70} & 0.15 & 0 & 12 & 10.5 & 1.575 \\
\hline & & & & & $\Sigma=4.2$ \\
\hline
\end{tabular}

$\overline{\text { Summation indicates sum (Mean mortality } x \text { Concentration difference) } \mathrm{LC}_{50} \text { for } \mathrm{LC}_{100}-\Sigma \text { (Mean mortality } \times \text { Concentration difference)/ }}$ number of organisms per group untreated effluent $2.70-4.2 / 12=2.70-0.35=2.35 \%(\mathrm{v} / \mathrm{v})$ 
Table 3. $\mathrm{LC}_{50}$ determination value of the untreated fertilizer industry effluent in L. rohita for $96 \mathrm{~h}$ based on arithmetic method of Kärber (1931) as adopted by Dede and Kaglo (2001)

\begin{tabular}{|c|c|c|c|c|c|}
\hline $\begin{array}{c}\text { Concentration } \\
\%(v / v)\end{array}$ & $\begin{array}{l}\text { Concentration } \\
\text { difference }\end{array}$ & $\begin{array}{l}\text { Number of } \\
\text { alive fish }\end{array}$ & $\begin{array}{l}\text { Number of } \\
\text { dead fish }\end{array}$ & Mean mortality & $\begin{array}{c}\text { Mean mortality } \\
\text { x concentration } \\
\text { difference }\end{array}$ \\
\hline Control & 0 & 12 & 0 & 0 & 0 \\
\hline 0.75 & 0.75 & 10 & 2 & 1 & 0.75 \\
\hline 0.85 & 0.10 & 08 & 4 & 3 & 0.30 \\
\hline 0.90 & 0.10 & 05 & 7 & 5.50 & 0.55 \\
\hline 0.95 & 0.05 & 04 & 8 & 7.50 & 0.375 \\
\hline 1.00 & 0.05 & 2 & 10 & 9 & 0.45 \\
\hline \multirow[t]{2}{*}{1.05} & 0.05 & 0 & 12 & 11 & 0.55 \\
\hline & & & & & $\Sigma=2.975$ \\
\hline
\end{tabular}

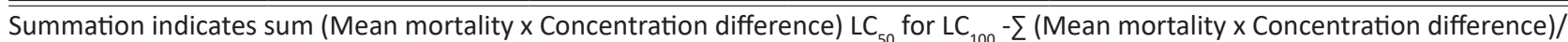
number of organisms per group untreated effluent $1.05-2.975 / 12=1.05-0.248=0.80 \%(\mathrm{v} / \mathrm{v})$

fertilizer industry effluents on this enzyme. The waste water released from fertilizer industry contains various contaminants which may act synergistically and if accumulated by inhibiting AChE activity may pose serious threat to the inhabiting species (Matthiessen et al., 1993; Bocquene et al., 1995; Forget et al., 1999; Larry et al., 2006). Hence, measurement of fish AChE activity has been considered as a suitable indicator for biomonitoring aquatic/industrial pollution (Jebali et al., 2013). The results further indicate that this effluent may act on AChE as a key target for its action. The negative impact caused by the untreated effluent, such as decrease in AChE activity and protein content in fish tissues (Fig 2 and 3 ), could be attributed to the presence of certain heavy metals and ammonia in it which may bind irreversibly on active site (Ravindra, 1999). The physical factors of fertilizer industry effluent such as dissolved oxygen, $\mathrm{pH}$, temperature and salinity may also influence certain biochemical indices in both fishes by altering multiple pathways (Bobmanuel et al., 2006; Kumari et al., 2010). In aquatic ecosystems, fertilizer industry effluent containing low concentrations (Sultana and Rao, 1998) of zinc may cause tissue damage by reacting with proteins and could also affect the respiratory efficiency, ion exchange and osmoregulatory function of the organs (Lloyd, 1992). The heavy metals present in the effluent in association with other chemicals may distort the cell organelles and alter the activity of several enzymes (Jan et al., 2015). This may disturb the physiological status of the exposed fishes, $H$. fossilis and L. rohita. In conclusion, the untreated fertilizer industry effluent has a deleterious impact in both fishes at high sublethal concentrations by inducing significant alterations in the activity of AChE in various fish tissues. The results indicated that the contents present in this effluent specifically targeted neurotransmission system individually and/or synergistically. Even though the fertilizer industry effluent at high concentrations markedly affected the fish organs tested, the magnitude of response varied from the one organ to the other. The decline in AChE activity could be considered as a useful tool for the assessment of industrial effluent toxicity, as it has been the case for other xenobiotic compounds such as organophosphate pesticides and heavy metals (Yadav et al., 2009; Rajkumar and Milton, 2011; Al-Ghais, 2013; Ramesh and Nagarajan, 2016; Tiwari et al., 2017).

\section{CONCLUSION}

The physico-chemical characteristics of the untreated fertilizer industry effluent sample exhibited high $\mathrm{pH}$, conductivity, free ammonia, chloride and chromium while low dissolved oxygen, iron and nitrate might be the reason for its high toxicity. The treated effluent sample had no toxic effect even when undiluted. This may be due to the fact that the physico-chemical parameters were in defined range of ISO guidelines (BIS 10500, 1991, 2003). The sublethal exposure of the untreated effluent sample clearly resulted in an inhibitory effect on the AChE activity in a concentration-dependent manner. These results indicate impairment of neuronal signalling on exposure to fertilizer industry effluent. However, further biochemical and molecular studies may help in better understanding of the mechanism of action of fertilizer industrial pollutants. The Government of India has made it mandatory for all industries to treat their effluents properly before their discharge. However, accidental discharge or inadequate management of untreated effluents may have disastrous effect on aquatic organisms. 


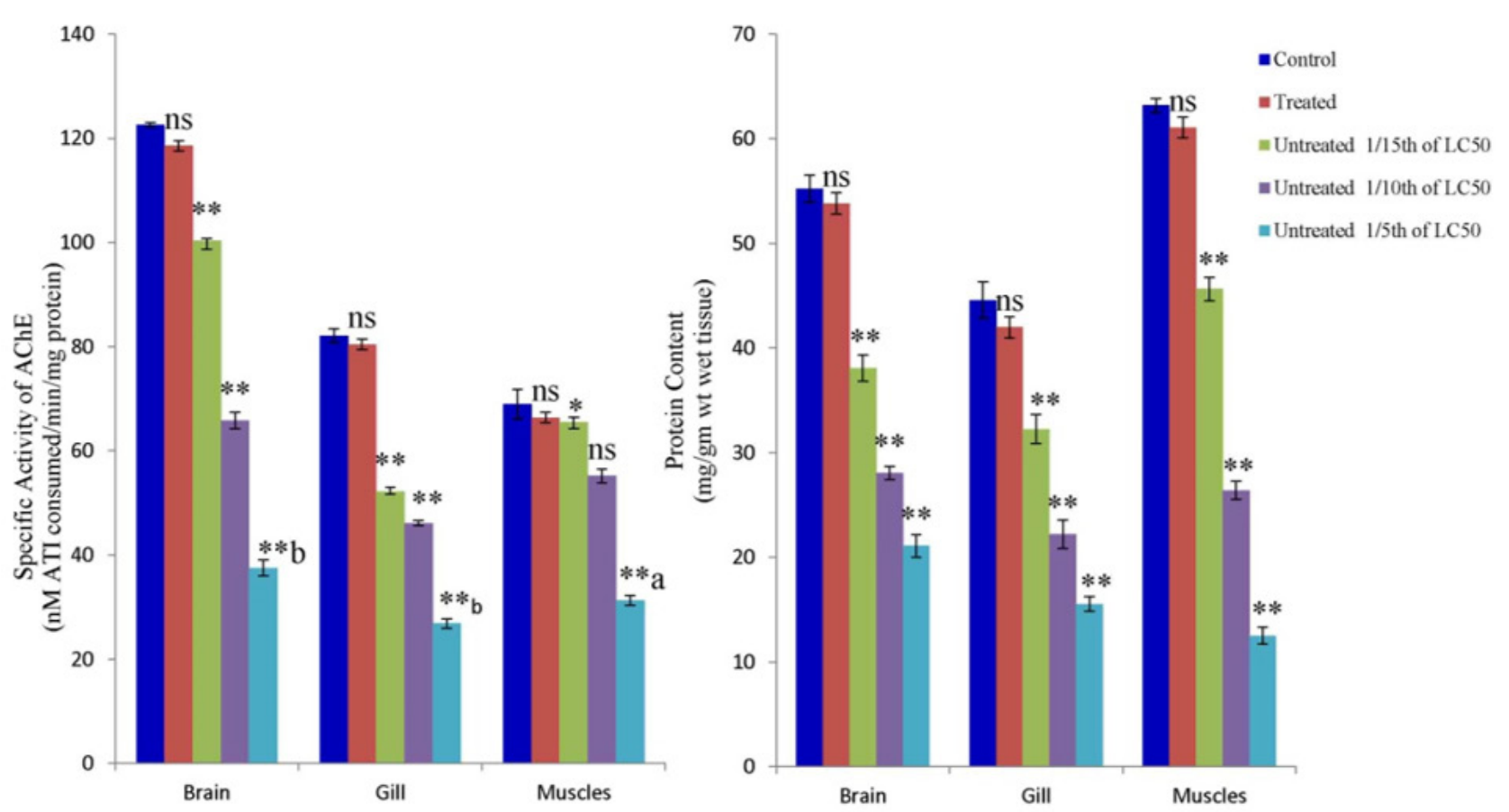

Fig 2. Specific activity of AChE (nM ATI/min/mg protein) and protein content (mg/gm wet wt. of tissue) in brain, muscle and gills of $H$. fossilis exposed to the untreated and treated fertilizer industry effluent. Data represent mean $\pm \mathrm{S}$. E. M. ( ${ }^{* *} \mathrm{p}<0.01 ;$ Control versus $1 / 15^{\text {th }}, 1 / 10^{\text {th }}$ and $1 / 5^{\text {th }}$ of $\mathrm{LC}_{50}$. $\mathrm{b} \mathrm{p}<0.01$; Control versus $1 / 15^{\text {th }}, 1 / 10^{\text {th }}$ and $1 / 5^{\text {th }}$ of $\mathrm{LC}_{50}$ and a $\mathrm{p}<0.05 ;$ Control versus $1 / 15^{\text {th }}, 1 / 10^{\text {th }}$ and $1 / 5^{\text {th }}$ of $\mathrm{LC}_{50}$; ns- not significant).
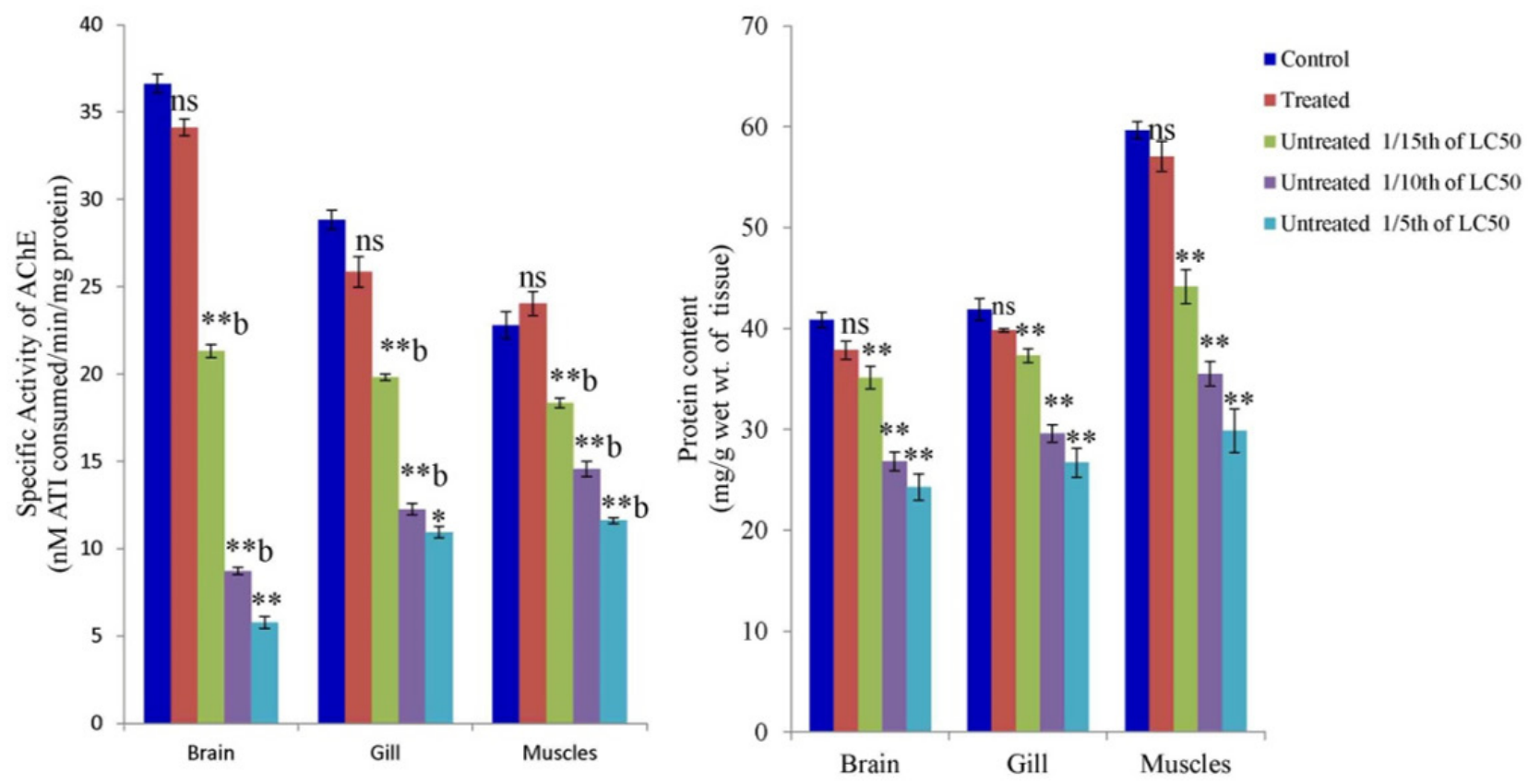

Fig 3. Specific activity of AChE ( $\mathrm{nM} \mathrm{ATI/min/mg} \mathrm{protein)} \mathrm{and} \mathrm{protein} \mathrm{content} \mathrm{(mg/gm} \mathrm{wet} \mathrm{wt.} \mathrm{of} \mathrm{tissue)} \mathrm{in} \mathrm{brain,} \mathrm{muscle} \mathrm{and} \mathrm{gills} \mathrm{of}$ L. rohita exposed to the untreated and treated fertilizer industry effluent. Data represent mean $\pm \mathrm{S}$. E. M. ( ${ }^{* *} \mathrm{p}<0.01 ;$ Control versus $1 / 15^{\text {th }}, 1 / 10^{\text {th }}$ and $1 / 5^{\text {th }}$ of $\mathrm{LC}_{50}$. $\mathrm{b} \mathrm{p}<0.01$; Control versus $1 / 15^{\text {th }}, 1 / 10^{\text {th }}$ and $1 / 5^{\text {th }}$ of $\mathrm{LC}_{50}$ and a $\mathrm{p}<0.05 ;$ Control versus $1 / 15^{\text {th }}, 1 / 10^{\text {th }}$ and $1 / 5^{\text {th }}$ of $\mathrm{LC}_{50}$; ns- not significant). 


\section{ACKNOWLEDGEMENT}

Authors express their gratitude to the Head of Department of Zoology for providing Central Instrumental facility developed with the assistance from DST-FIST and UGC-SAP phase I \& II for carrying out this work. Financial assistance to one of the authors (US) from UGC is gratefully acknowledged.

\section{SAŽETAK}

\section{FIZIKALNO-KEMIJSKE ZNAČAJKE OTPADNIH VODA INDUSTRIJE GNOJIVA I NJIHOV TOKSI- KOLOŠKI UTJECAJ NA AKTIVNOST ACETILKOLIN- ESTERAZE (AChE) KOD SLATKOVODNIH TELEOS- TA Heteropneustes fossilis I Labeo rohita}

Industrijska revolucija je dobar pokazatelj gospodarskog razvoja države, međutim, može biti i prijetnja za floru i faunu ako se u prirodu ispuštaju nepročišćene otpadne vode industrije. Cilj ovog istraživanja je procijeniti toksikološke učinke pročišćenih i nepročišćenih industrijskih otpadnih voda na aktivnost acetilkolinesteraze (AChE) kod Heteropneustes fossilis i Labeo rohita, jestivih riba različitih karakteristika poput razlika u morfologiji, staništu, ishrani, itd. Analizirani su fizikalno-kemijski parametri otpadnih voda kao što su: $\mathrm{pH}$, električna vodljivost (EC), alkalitet, tvrdoća, otopljeni kisik (DO), fosfati, sulfati, nitrati, slobodni amonijak, kloridi, cink, željezo, krom i kalij jer ti parametri nisu bili u rasponu prema ISO smjernicama. Vrijednost $\mathrm{LC}_{50}$ za nepročišćene vode iznosila je 2,34\% (v/v) i 0,80\% (v/v) tijekom $96 \mathrm{~h} \mathrm{kod}$ H. fossilis i L. rohita. Smrtnost riba u obrađenim otpadnim vodama nije zabilježena. Tijekom izlaganja subletalnim koncentracijama $\left(1 / 15,1 /(10), 1 / 5\right.$ LC $\left._{50}\right)$ kod obje vrste riba aktivnost AChE u metabolički osjetljivim organima (mozak, mišići, škrge) je bila smanjena. Daljnja istraživanja biokemijskih i molekularnih pokazatelja mogla bi približiti mehanizam njihovog djelovanja.

Ključne riječi: Aktivnost AChE, akutna toksičnost, Heteropneustes fossilis, Labeo rohita, otpadne vode industrije gnojiva, fizikalno-kemijske karakteristike

\section{REFERENCES}

Abdullah, M. H., Musta, B. (1999): Phreatic water quality of the turtle islands of East Malaysia: Pulau Selingaan and Pulau Bakkungan Kechil. Borneo Science, 6, 1-9.

Abedi, Z., Khalesi, M., Eskandari, S. K., Rahmani, H. (2012): Comparison of lethal concentrations $\left(\mathrm{LC}_{50}-96 \mathrm{~h}\right)$ of $\mathrm{CdCl}_{2}, \mathrm{CrCl}_{3}$, and $\mathrm{Pb}\left(\mathrm{NO}_{3}\right)_{2}$ in Common Carp (Cyprinus carpio) and Sutchi Catfish (Pangasius hypophthalmus). Iranian Journal of Toxicology, 6, 18, 672-680.
Al-Ghais, S. M. (2013): Acetylcholinesterase, glutathione and hepatosomatic index as potential biomarkers of sewage pollution and depuration in fish. Marine Pollution Bulletin, 74, 1, 183-186.

American Public Health Association (APHA) (1985): Standard methods for the examination of water and wastewater in $16^{\text {th }}$ ed. Washington, DC: APHA 1268.

Ahila Angelin, J., Steven Jones, R. D., Sam Manohar Das, S. (2015): Pre and post treatment toxicity of chrome plating industry effluent to Poecilia reticulata Peter 1859.International Journal of Fisheries and Aquatic Studies, 2, 4, 153-156.

Bhatnagar, A., Devi, P. (2013): Water quality guidelines for the Management of pond fish culture. International Journal of Environmental Science, 3,6, 1980-2009.

Bobmanuel, N. O. K., Gabriel, U. U., Ekweozor, I. K. E. (2006): Direct toxic assessment of treated fertilizer effluents to Orechromis niloticus, Clarias gariepinus and catfish hybrid (Heterobranchus bidorsalis $\hat{\delta} \times$ Clarias gariepinus + ). African Journal of Biotechnology, 5, 8, 635-642.

Bocquene, G., Bellanger, C., Cadiou, Y. (1995): Joint action of combinations of pollutants on the acetylcholinesterase activity of several marine species. Ecotoxicology, 4, 4, 266-279.

Brunning, J. L., Knitz, B. L. (1977): Computational hand book of statistics in $2^{\text {nd }}$ ed. Illinois: Scott, Foresman and Company, USA.

Bureau of Indian Standards (2003): Indian standards of drinking water-specification, BIS 10500: 1991. First revision.

Campbell, P. G. C., Stokes, P. M. (1985): Acidification and toxicity of Metals to Aquatic biota. Canadian Journal of Aquatic Sciences, 42, 2034-2049.

Chavan, M., Thacker, N. P., Tarar, J. L. (2016): Toxicity Evaluation of Pesticide Industry Wastewater through Fish Bioassay. International Journal of Applied Sciences, 3, 3, 331-339.

Das, S.M., Moitra, S. K. (1955): Studies on the food of some common fishes of Uttar Pradesh, India. 1. The surface feeders the mid-feeders and bottom feeders. Proceedings of the National Academy of Sciences, India, 25 (B), (1-2), 1-6.

Dede, E. B., Kaglo, H. D. (2001): Aqua-toxicological effects of water soluble fractions (WSF) of Diesel fuel effluent on Oreochromis niloticus fingerlings. Journal of Applied Sciences and Environmental Management, 5, 93-96.

Deshpande, A.M., Satyanarayan, S. (2011): Toxicity evaluation of through fish bioassay raw bulk drug industry wastewater after electrochemical treatment. Iranian Journal of Environmental Health Science and Engineering, 8, 373-380.

Durrani, G. F., Zahoor, A., Baloch, Musa. (2007): Analysis of physicochemical characteristics of industrial effluents of HIE (Industrial state) Haripur. Journal-Chemical Society of Pakistan, 29, 328-331. 
Ellman, G. L., Courtney, D., Andreas, V. J., Featherstone, R. M. (1961): A new and rapid colorimetric determination of acetylcholinesterase activity. Biochemical Pharmacology, 7, 88-96.

El-Samara, M. I., Ibrahium, M. A., Ahmed, I. F., Awartani, S. M. (1986): Acute toxicity of some oil dispersants to mullet fry Liza macrolepis of the Arabian Gulf. Qatar University Science Bulletin, 6, 363-369.

Forget, J., Pavillon, J. F., Beliaeff, B., Bocquene, G. (1999): Joint action of pollutant combinations (pesticides and metals) on survival ( $\mathrm{LC}_{50}$ values) and Acetylcholinesterase activity of Tigriopus brevicornis (Copepoda, Harpacticoida). Environmental Toxicology and Chemistry, 18, 912-918.

Gaitonde, D., Sarkar, A., Kaisary, S., Silva, C. D., Dias, C., Rao, D. P., Ray, D., Nagarajan, R., De Sausa, S. N., Sarkar, S., Patil, D. (2006): Acetylcholinesterase activities in marine snail (Cronia contracta) as a biomarker of neurotoxic contaminants along the Goa coast, West coast of India. Ecotoxicology, 15, 4, 353-358.

Grubb, D. G., Guimarates, M. S., Valenica, R. (2000): Phosphate immobilization using an acidic type fly ash. Journal of Hazardous Material, 76, 217-236.

Horrigan, L., Lawrence, R. S., Walker, P. (2002): How sustainable agriculture can address the environmental and human health harms of industrial agriculture. Environmental Health Perspectives, 110, 445-456.

Jadhav, U., Hocheng, H. (2012): A review of recovery of metals from industrial waste. Journal of Achievements in Materials and Manufacturing Engineering, 54, 159167.

Jan, A. T., Azam, M., Siddiqui, K., Ali, A., Choi, I., Haq, M. Q. R. (2015): Heavy metals and human health: Mechanistic insight into toxicity and counter defence system of antioxidants. International Journal of Molecular Sciences, 16, 12, 29592-29630.

Jawad, L. A. (2015): The Indian catfish, Heteropneustes fossilis (Bloch, 1794) Envenomation- A report of four cases from Basrah and Maysan, South of Iraq. Journal of Medical Sciences, 2, 2, 52-61.

Jebali, J., Khedher, S. B., Sabbagh, M., Kamel, N., Banni, M., Boussetta, H. (2013): Cholinesterase activity as biomarker of neurotoxicity: utility in the assessment of aquatic environment contamination. Journal of Integrated Coastal Zone Management, 13, 4, 525-537.

Kärber G. (1931): Beitrag zur kollektiven Behandlung pharmakologischer Reihenversuche NaunynSchmiedebergs Archiv für experimentelle Pathologie und Pharmakologie, 162, 480-483.

Karthikeyan, R., Vijayalakshmi, S., Balasubramanian, T. (2004): Seasonal distribution of heavy metals in the sediments from Uppanar estuary (East coast of India). Journal of Aquatic Biology, 19, 2, 119-122.

Kaur, A., Vats, S., Rekhi, S., Bhardwaj, A., Goel, J., Tanwar, R. S., Gaur, K. K. (2010): Physico-chemical analysis of the industrial effluents and their impact on the soil microflora. Procedia Environmental Sciences, 2, 595-
599.

Kumar, N., Sinha, D. K. (2010): Drinking water quality management through correlation studies among various physicochemical parameters: A case study. International Journal of Environmental Sciences, 1, 253-259.

Kumari, K., Ranjan, N., Sinha, R. C. (2010): Effect of endosulfan on the absorption of $\alpha$ and $\beta$ chains of hemoglobin and Acetylcholinestrate activity in the fish, Labeo rohita. The Journal of V. N. Karazin Kharkiv and National University, 12, 83-89.

Larry, B. B., Staffanie, H. K., Ronald, C. A., Howard, E. T., Ronald, D. W. (2006): Accumulation of contaminants in fish from wastewater treatment wetlands. Environmental Science \& Technology, 40, 2, 603-611.

Lloyd, R. (1992): Pollution and Freshwater fish. In Fishingnews books. Oxford: Finishing news books. Division of Blackwell Scientific Publications Ltd, UK., 176.

Lowry, O. H., Rosebrough, N. J., Farr, A. L., Randel, R. J. (1951): Protein measurement with Folin-phenol reagent. The Journal of Biological Chemistry, 193, 265275.

Majumdar, J., Baruah, B. K., Dutta, K. (2007): Evaluation of $\mathrm{LC}_{50}$ of galvanizing industry effluent. Journal of Industrial Pollution Control, 23, 1, 131-134.

Matthiessen, P., Thain, J. E., Law, R. J., Fileman, T. W. (1993): Attempts to assess the environmental hazard posed by complex mixtures of organic chemicals in UK estuaries. Marine Pollution Bulletin, 26, 2, 90-95.

Ministry of Environment, Forest and Climate Change, Government of India. (2016): Environment Ministry releases new categorisation of industries in Press Information Bureau, Government of India. [Cited2018 January 11]. Available on http://pib.nic.in/newsite/ PrintRelease. aspx? relid $=137373$

Muley, D. V., Karanjkar, D. M., Maske, S. V. (2007): Impact of industrial effluents on the biochemical composition of fresh water fish, Labeo rohita. Journal of Environmental Biology, 28, 245-249.

Naigaga, I., Kaiser, H., Muller, W. J., Ojok, L., Mbabzi, D., Magezi, G., Muhumuza, E. (2011): Fish as bioindicators in aquatic environmental pollution assessment: A case study in Victoria wetlands, Uganda. Physics and Chemistry of the Earth, parts A/B/C, 36, 14-15, 918928.

Nirgude, N. T., Shukla, S., Venkatachalam, A. (2013): Physico-chemical analysis of some industrial effluents from Vapi industrial area, Gujarat, India. Rasayan Journal of Chemistry, 6, 1, 68-72.

Obasi, A. I., Amaeze, N. H., Osoko, D. D. (2014): Microbological and toxicological assessment of pharmaceutical wastewater from the Lagos Megacity, Nigeria. Chinese Journal of Biology, 1-9.

Pati, A. K.,Maheshwari, R., Gupta, S. (1998): Opercular activity and temporal organization of surfacing behaviour in Indian catfishes, Clarias batrachus and Heteropneustes fossilis. Biological Rhythm Research, 
29, 1, 75-85.

Praveena, M., Sandeep, V., Kavitha, N., Rao, J. K. (2013): Impact of tannery effluent, Chromium on haematological parameters in a fresh water fish Labeo rohita (Hamilton). Research Journal of Animal, Veterinary and Fishery Sciences, 1, 6, 1-5.

Rajkumar, J. S. I., Milton, M. C. J. (2011): Biochemical marker of oxidative stress in Mugilcephalus exposed to cadmium, copper, lead and zinc. International Journalof Pharma and Bio Sciences, 2, 3, 41-40.

Rakhi, S. F., Reza, A. H. M. M., Hosen, M. S., Hossain, Z. (2013): Alterations in Histopathological features and brain acetylcholinesterase activity in stinging catfish Heteropneustes fossilis exposed to polluted river water. International Aquatic Research, 5, 5-7.

Ramesh, F., Nagarajan, K. (2016): Influence of sago effluent on the levels of the enzyme cholinesterase in the brain tissue of the fresh water fish Clarias batrachus. Advances in Bioscience and Bioengineering, 1, 1, 3543.

Ravindra, K. (1999): Impact of ammonia stress on Acetylcholinesterase (AChE) activity in blood and brain of Snake head fish Channa punctatus (Bloch). Journal of Environmental Pollution, 6, 2\&3, 203-205.

Richetti, S. K., Rosemberg, D. B., Ventura-Lima, J., Monserrat, J. M., Bogo, M. R., Bonan, C. D. (2011): Acetylcholinesterase activity and antioxidant capacity of zebra fish brain is altered by heavy metal exposure. Neurotoxicology, 32, 1, 116-122.

Roopadevi, H., Somashekar, R. K. (2012): Assessment of the toxicity of waste water from a textile industry to Cyprinus carpio. Journal of Environmental Biology, 33, 167-171.

Sah, S. K., Acharya, P., Lance, V. A. (2002): Effect of industrial pollution in fish in the Narayani river, central Nepal. Nepal Journal of Sciences and Technology, 4, 5-14.

Shenkani, K., Sam Manohar Das, S. (2014): Toxicity of rubber wood processing effluent exposed to fresh water fish Poecilia reticulate. Journal of Entomology and Zoological Studies, 2, 6, 326-329.

Shreelekshmy, S. G., Mirinda, M. T. P., Rajesh, B. R. (2016): Acute toxicity of industrial effluent on the marine catfish Aurius nenga (Hamilton, 1822). International Journal of Fisheries and Aquatic Sciences, 4, 3, 215219.
Sprague, J. B. (1969): Measurement of pollutant of toxicity of fish, bioassay methods for acute toxicity. Water Research, 3, 11, 793-821.

SPSS 16.0.2. (2008): Command syntax reference, SPSS Inc, Chicago III.

Sultana, R., Rao, D. P. (1998): Bioaccumulation patterns of zinc, copper, lead and cadmium in grey mullet, Mugil cephalus (L.), from harbour waters of Vishakhapatnam, India. Bulletin of Environmental Contamination and Toxicology, 60, 6, 949-945.

Talwar, P. K., Jhingran, A. G. (1991): Inland fishes of India and adjacent countries. pp. 689-690. In Oxford \& IBH Publishing Co. Pvt. Ltd, (Vols. 1 \& 2) New Delhi, India. $1097 \mathrm{pp}$.

Tiwari, R. K., Singh, S., Pandey, R. S. (2017): Assessment of the acute toxicity of chlorpyrifos and cypermethrin to Heteropneustes fossilis and their impact on acetylcholinesterase activity. Drug and Chemical Toxicology, 1-8.

Valbonesi, P., Sartor, G., Fabbri, E. (2003): Characterization of cholinesterase activity in three bivalves inhabiting the North Adriatic sea and their possible use as sentinel organisms for bio surveillance programmes. Science of The Total Environment, 312, 79-88.

Wicklund-Glynn, A., Olsson, P. E. (1991): Cadmium turnover in minnows, Phoxinus phoxinus pre-exposed to waterborne cadmium. Environmental Toxicology and Chemistry, 10, 383-394.

Xuereb, B., Chaumot, A., Mons, R., Garric, J., Geffard, O. (2009): Acetylcholinesterase activity in Gammarus fosarum (Crustacea, Amphipoda) Intrinsic variability, reference levels and a reliable tool for field surveys. Aquatic Toxicology, 93, 4, 225-233.

Yadav, A., Gopesh, A., Pandey, R. S., Rai, D. K., Sharma, B. (2009): Acetylcholinesterase: a potential biochemical indicator for biomonitoring of fertilizer industry effluent toxicity in freshwater teleost, Channa striatus. Ecotoxicology, 18, 3, 325-333.

Yadav, A., Neraliya, S., Gopesh, A. (2007): Acute toxicity levels and ethological responses of Channa striatus to fertilizer industrial wastewater. Journal of Environmental Biology, 28, 2, 159-162. 